\title{
FAKTOR-FAKTOR YANG BERHUBUNGAN DENGAN PERTUMBUHAN BADUTA (UMUR 7-24 BULAN) DI WILAYAH KERJA PUSKESMAS PENENGAHAN KABUPATEN LAMPUNG SELATAN
}

\author{
Hanasiah $^{1}$, Anita ${ }^{2}$, Zaenal Abidin ${ }^{3}$ \\ ${ }^{1}$ Puskesmas Penengahan Kabupaten Lampung Selatan \\ ${ }^{2}$ Jurusan Keperawatan Poltekkes Tanjungkarang \\ ${ }^{3}$ Fakultas Kesehatan Masyarakat, Universitas Malahayati Bandar Lampung \\ Email: hanasiah77@yahoo.co.id
}

\begin{abstract}
Related Factors to Growths of Children Under Two Years (7-24 Months) in Penengahan Public Health Center Working Areas, South Lampung District. The proportion of malnutrition and lack of nutrition in Penengahan PHC working areas were $11.28 \%$ in 2012, $12.29 \%$ in $2013,13.01 \%$ in 2014 , and $12.97 \%$ in 2015 . The objective of this research was to find out the factors related to the growths of children under two years (7-24 months) in Penengahan PHC working areas, South Lampung District in 2015. This was an analytic and quantitative observational research with case control design. Population after restriction was 1731 of children under two years (7-24 months) in 2015, containing of 343 case population and 1388 control population. 156 respondent were divided in 1:1 for case and control. The samples were taken by using circular systematic sampling and determined by using case control sampling formula by testing hypothesis to OR with $\alpha=5 \%$ and $\beta=5 \%$. Data were analyzed by using univariate, bivariate, and multivariate (Chi Square test and Multiple Logistic Regression at $\alpha=5 \%$ ). The results are the following: (1) there were $64.7 \%$ respondents had elementary school education, $23.1 \%$ respondents were working, $53.8 \%$ mothers had less knowledge, $39.1 \%$ respondents had child's disease history, and $64.7 \%$ respondents had poor nursing patterns; (2) that variables of maternal education level $(\mathrm{p}=0.001, \mathrm{OR}=3.7)$, maternal occupation status $(\mathrm{p}=0.004, \mathrm{OR}=3.7)$, child's disease history $(\mathrm{p}=0.001, \mathrm{OR}=3.8)$, and nursing pattern $(\mathrm{p}=0.019, \mathrm{OR}=2.4)$ simultaneously related to the growth of children under two years.
\end{abstract}

Keywords: Growth, Education, Occupation, Knowledge, Disease History, Nursing Pattern

\begin{abstract}
Abstrak: Faktor-Faktor yang Berhubungan dengan Pertumbuhan Baduta (Umur 7-24 Bulan) di Wilayah Kerja Puskesmas Penengahan Kabupaten Lampung Selatan. Proporsi gizi buruk \& gizi kurang di wilayah kerja Puskesmas Penengahan pada 2012: 11,28\%; 2013: 12,29\%; 2014: 13,01\%; dan 2015: 12,97\%. Tujuan penelitian ini adalah diketahuinya faktor-faktor yang berhubungan dengan pertumbuhan Baduta (umur 7-24 bulan) di wilayah kerja Puskesmas Penengahan Kabupaten Lampung Selatan 2015. Jenis penelitian ini kuantitatif analitik observasional dengan rancangan Case Control. Populasi setelah restriksi sebanyak 1731 Baduta (umur 7-24 bulan) tahun 2015, yaitu populasi kasus 343 dan populasi kontrol 1388. Sampel 156 terdiri dari sampel kasus \& kontrol dengan perbandingan 1:1, yang ditetapkan dari hasil perhitungan rumus sampel Case Control pengujian hipotesis terhadap OR dengan $\alpha=5 \%, \beta=5 \%$, dan diambil dengan Circular Systematic Sampling. Analisis data: univariat, bivariat, dan multivariat dengan uji Chi Square dan Regresi Logistik Ganda, $\alpha=5 \%$. Hasil penelitian: 1) terdapat $64,7 \%$ ibu dengan tingkat pendidikan dasar, $23,1 \%$ ibu bekerja, 53,8\% ibu dengan pengetahuan kurang, $39,1 \%$ ada riwayat penyakit anak, $64,7 \%$ pola asuh kurang baik. 2) variabel yang secara bersama-sama berhubungan dengan pertumbuhan Baduta, yaitu riwayat penyakit anak $(\mathrm{p}=0,001$, $\mathrm{OR}=3,8)$, status pekerjaan ibu $(\mathrm{p}=0,004, \mathrm{OR}=3,7)$, tingkat pendidikan ibu $(\mathrm{p}=0,001, \mathrm{OR}=3,7)$, dan pola asuh $(\mathrm{p}=0,019, \mathrm{OR}=2,4)$.
\end{abstract}

Kata Kunci: Pertumbuhan, Pendidikan, Pekerjaan, Pengetahuan, Riwayat Penyakit, Pola Asuh

Masa pertumbuhan anak yang relatif pendek, merupakan masa yang menentukan kualitas hidup pada masa dewasa. Sebagai aset bangsa, anak harus mendapat perhatian sejak mereka masih dalam kandungan sampai menjadi manusia dewasa (Soetjiningsih, 2014).

Penilaian tumbuh kembang (tumbang) perlu dilakukan untuk menentukan tumbang anak 
berjalan normal atau tidak. Anak yang sehat akan menunjukkan tumbang optimal, jika diberikan lingkungan biofisiko-psikososial yang adekuat. Salah satu cermin tumbang balita dapat dipantau dari status gizi balita. Pemantauan status gizi balita adalah salah satu upaya pemantauan tumbang balita (Soetjiningsih, 2014).

Indonesia termasuk di antara 36 negara di dunia yang berkontribusi $90 \%$ terhadap masalah gizi dunia (Fauzi, 2011). Masalah terkait pertumbuhan balita di Indonesia dapat diketahui dari proporsi balita kurang gizi dan proporsi balita yang menderita gizi buruk secara nasional. Berdasarkan hasil Riskesdas (2013) diketahui bahwa, proporsi balita kurang gizi secara nasional 2007-2013 kecenderungannya fluktuatif. Tahun 2007 terdapat 18,4\% balita kekurangan gizi, tahun 2010 terdapat $17,9 \%$ balita kekurangan gizi, tahun 2013 terdapat 19,6\% balita kekurangan gizi. Proporsi gizi kurang pada balita di Provinsi Lampung tahun 2007-2013 berada dibawah angka nasional, tetapi kecenderungannya fluktuatif. Pada 2007 terdapat $18 \%$ kasus balita gizi kurang, menurun pada 2010 menjadi 14\%, kemudian meningkat pada 2013 menjadi $19 \%$.

Tahun 2014 kabupaten Lampung Selatan urutan ketiga prosentase balita gizi buruk dari 14 kabupaten/kota di provinsi Lampung dengan kasus 16 balita gizi buruk, kabupaten Lampung Tengah urutan kedua dengan 21 kasus balita gizi buruk, sedangkan urutan pertama adalah kabupaten Lampung Timur sebanyak 27 kasus balita gizi buruk ( Dinkes Prov. Lampung, 2015). Puskesmas Penengahan kabupaten Lampung Selatan pada kurun waktu 2012-2015 terdapat kasus gizi buruk, gizi kurang, dan gizi lebih. Proporsi gizi buruk dan gizi kurang tahun 2012 sebesar 11,28\%, tahun 2013 sebesar 12,29\%, tahun 2014 sebesar 13,02\%, tahun 2015 sebesar $12,97 \%$. Kasus gizi buruk dan gizi kurang tahun 2015 tersebut terjadi pada anak Baduta (umur $7-24$ bulan) sebesar 55,5\%.

Tumbuh kembang mencakup dua peristiwa yang sifatnya berbeda, tetapi saling berkaitan dan sulit dipisahkan, yaitu pertumbuhan dan perkembangan. Pertumbuhan berkaitan dengan masalah perubahan dalam besar, jumlah, ukuran atau dimensi tingkat sel, organ maupun individu, yang bisa diukur dengan ukuran berat, ukuran panjang, umur tulang, dan keseimbangan metabolik (retensi kalsium dan nitrogen tubuh).
Tumbuh kembang anak menurut UNICEF dan Jonsson dipengaruhi oleh faktor lingkungan yang terdiri dari sebab langsung (kecukupan makanan dan keadaan kesehatan), sebab tidak langsung (ketahanan makanan keluarga, asuhan bagi ibu dan anak/pola asuh, dan pemanfaatan yankes, sanitasi lingkungan), dan penyebab dasar (potensi sumber daya yang mempengaruhi penyebab dasar lainnya yaitu struktur ekonomi, struktur politik dan ideologi) (Soetjiningsih, 2014).

Berdasarkan latar belakang tersebut maka perlu diadakan penelitian yang bertujuan mengetahui faktor-faktor yang berhubungan dengan pertumbuhan Baduta (umur 7-24 bulan) di wilayah kerja Puskesmas Penengahan Kab. Lampung Selatan.

\section{METODE PENELITIAN}

Jenis penelitian ini adalah kuantitatif analitik observasional dengan rancangan Case Control. Populasi setelah restriksi sebanyak 1731 Baduta (umur 7-24 bulan) tahun 2015, yaitu populasi kasus 343 dan populasi kontrol 1388. Sampel 156 terdiri dari sampel kasus \& kontrol dengan perbandingan $1: 1$, yang ditetapkan dari hasil perhitungan rumus sampel Case Control pengujian hipotesis terhadap OR dengan $\alpha=5 \%$ dan $\beta=5 \%$, dan diambil dengan Circular Systematic Sampling.

Variabel penelitian yaitu pertumbuhan Baduta, tingkat pendidikan ibu, status pekerjaan ibu, pengetahuan ibu, riwayat penyakit anak, pola asuh.

Instrumen penelitian ini adalah timbangan berat badan, formulir observasi, dan kuisioner. Pengolahan data terdiri dari pemeriksaan dan pembersihan data, pemberian kode, dan pemrosesan. Analisis data terdiri dari univariat, bivariat, dan multivariat dengan uji $C h i$ Square dan Regresi Logistik Ganda, $\alpha=5 \%$.

\section{HASIL}

\section{A. ANALISIS UNIVARIAT}

Berdasarkan pengumpulan data dan pengolahan data diperoleh deskripsi tiap-tiap variabel penelitian, sebagaimana tampak pada tabel 1 berikut ini: 
Tabel 1. Distribusi Statistik Variabel Penelitian

\begin{tabular}{|c|c|c|c|c|c|c|c|}
\hline \multirow{2}{*}{ Variabel } & & \multicolumn{2}{|c|}{ Kasus } & \multicolumn{2}{|c|}{ Kontrol } & \multicolumn{2}{|c|}{ Jumlah } \\
\hline & & $\mathbf{n}$ & $\%$ & $\mathbf{n}$ & $\%$ & $\mathbf{n}$ & $\%$ \\
\hline \multirow{3}{*}{ Tingkat Pendidikan Ibu } & Pendidikan Dasar & 57 & 73,1 & 44 & 56,4 & 101 & 64,7 \\
\hline & Pendidikan Menengah/Tinggi & 21 & 26,9 & 34 & 43,6 & 55 & 35,3 \\
\hline & Jumlah & 78 & 100 & 78 & 100 & 156 & 100 \\
\hline \multirow{3}{*}{ Status Pekerjaan Ibu } & Bekerja & 24 & 30,8 & 12 & 15,4 & 36 & 23,1 \\
\hline & Tidak Bekerja & 54 & 69,2 & 66 & 84,6 & 120 & 76,9 \\
\hline & Jumlah & 78 & 100 & 78 & 100 & 156 & 100 \\
\hline \multirow{3}{*}{ Tingkat Pengetahuan Ibu } & Pengetahuan Kurang & 49 & 62,8 & 35 & 44,9 & 84 & 53,8 \\
\hline & Pengetahuan Baik & 29 & 37,2 & 43 & 55,1 & 72 & 46,2 \\
\hline & Jumlah & 78 & 100 & 78 & 100 & 156 & 100 \\
\hline \multirow{3}{*}{ Riwayat Penyakit Anak } & Ada Riwayat & 40 & 51,3 & 21 & 26,9 & 61 & 39,1 \\
\hline & Tidak Ada Riwayat & 38 & 48,7 & 57 & 73,1 & 95 & 60,9 \\
\hline & Jumlah & 78 & 100 & 78 & 100 & 156 & 100 \\
\hline \multirow{3}{*}{ Pola Asuh } & Kurang Baik & 57 & 73,1 & 44 & 56,4 & 101 & 64,7 \\
\hline & Baik & 21 & 26,9 & 34 & 43,6 & 55 & 35,3 \\
\hline & Jumlah & 78 & 100 & 78 & 100 & 156 & 100 \\
\hline
\end{tabular}

Deskriptif hasil penelitian ini berdasarkan tabel 1 tersebut di atas, yaitu di wilayah kerja Puskesmas Penengahan 2015 diketahui, sebagai berikut : Terdapat lebih dari separuh $(64,7 \%)$ ibu yang mempunyai Baduta dengan katagori tingkat pendidikan dasar. Pada kelompok kasus, terdapat hampir mencapai tiga perempat $(73,1 \%)$ Ibu Baduta dengan tingkat pendidikan dasar dan lebih banyak dibandingkan Ibu Baduta dengan tingkat pendidikan menengah/tinggi $(26,9 \%)$.

Terdapat kurang dari seperempat $(23,1 \%)$ ibu yang mempunyai Baduta dengan katagori bekerja. Pada kelompok kasus, terdapat lebih dari seperempat $(30,8 \%)$ Ibu Baduta yang bekerja, dan lebih sedikit dibandingkan Ibu Baduta yang tidak bekerja $(69,2 \%)$.

Terdapat lebih dari separuh $(53,8 \%)$ ibu yang mempunyai Baduta dengan katagori tingkat pengetahuan kurang. Pada kelompok kasus, terdapat lebih dari separuh $(62,8 \%)$ ibu Baduta dengan tingkat pengetahuan kurang, dan lebih banyak dibandingkan ibu Baduta dengan tingkat pengetahuan baik $(37,2 \%)$.

Terdapat lebih dari seperempat $(39,1 \%)$ Baduta dengan katagori ada riwayat penyakit. Pada kelompok kasus, terdapat lebih dari separuh $(51,3 \%)$ Baduta dengan katagori ada riwayat penyakit, dan lebih banyak dibandingkan Baduta dengan katagori tidak ada riwayat penyakit $(48,7 \%)$.

Terdapat lebih dari separuh $(64,7 \%)$ Baduta dengan katagori pola asuh kurang baik. Pada kelompok kasus, terdapat hampir mencapai tiga perempat $(73,1 \%)$ Baduta dengan katagori pola asuh kurang baik, dan lebih banyak dibandingkan Baduta dengan katagori pola asuh baik $(26,9 \%)$.

\section{B. ANALISIS BIVARIAT}

Berdasarkan pengumpulan data dan pengolahan data diperoleh hasil bivariat penelitian ini, sebagaimana tampak pada tabel 2 . Hasil uji statistik antara tingkat pendidikan ibu dengan pertumbuhan Baduta diperoleh nilai $p=0,044$ lebih kecil dari $\alpha=0,05$ yang artinya ada hubungan yang bermakna antara tingkat pendidikan ibu dengan pertumbuhan Baduta. Hasil uji statistik juga diperoleh $\mathrm{OR}=2,1$ artinya ibu yang mempunyai tingkat pendidikan dasar merupakan risiko 2,1 kali untuk mengalami pertumbuhan Baduta tidak baik dibandingkan dengan ibu yang mempunyai tingkat pendidikan menengah/tinggi.

Hasil uji statistik antara status pekerjaan ibu dengan pertumbuhan Baduta diperoleh nilai $p=0,037$ lebih kecil dari $\alpha=0,05$ yang artinya ada hubungan bermakna antara status pekerjaan ibu dengan pertumbuhan Baduta. Hasil uji statistik juga diperoleh $\mathrm{OR}=2,4$ yang artinya status pekerjaan ibu yang bekerja merupakan risiko 2,4 kali untuk mengalami pertumbuhan Baduta tidak baik dibandingkan dengan ibu yang tidak bekerja.

Hasil uji statistik antara pengetahuan ibu dengan pertumbuhan Baduta diperoleh nilai $p=0,037$ lebih kecil dari $\alpha=0,05$ yang artinya ada hubungan bermakna antara pengetahuan ibu dengan pertumbuhan Baduta. Hasil uji statistik juga diperoleh $\mathrm{OR}=2,1$ yang artinya pengetahuan ibu kurang baik merupakan risiko 2,1 kali untuk mengalami pertumbuhan Baduta tidak baik dibandingkan pengetahuan ibu yang baik.

Hasil uji statistik antara riwayat penyakit anak dengan pertumbuhan Baduta diperoleh nilai 
$p=0,003$ lebih kecil dari $\alpha=0,05$ yang artinya ada hubungan bermakna antara riwayat penyakit anak dengan pertumbuhan Baduta. Hasil uji statistik juga diperoleh $\mathrm{OR}=2,9$ artinya anak yang ada riwayat penyakit anak merupakan risiko 2,9 kali untuk mengalami pertumbuhan Baduta tidak baik dibandingkan dengan yang tidak ada riwayat penyakit anak.
Hasil uji statistik antara pola asuh dengan pertumbuhan Baduta diperoleh nilai $p=0,044$ lebih kecil dari $\alpha=0,05$ yang artinya ada hubungan bermakna antara pola asuh dengan pertumbuhan Baduta. Hasil uji statistik juga diperoleh $\mathrm{OR}=2,1$ yang artinya pola asuh tidak baik merupakan risiko 2,1 kali untuk mengalami pertumbuhan Baduta tidak baik dibandingkan dengan pola asuh yang baik.

Tabel 2. Hubungan Masing-masing Variabel dengan Pertumbuhan Baduta

\begin{tabular}{|c|c|c|c|c|c|c|c|c|}
\hline \multirow{3}{*}{ Variabel } & & \multicolumn{4}{|c|}{ Pertumbuhan Baduta } & \multirow{3}{*}{$\begin{array}{c}\text { Jumlah } \\
\mathbf{n} \\
\end{array}$} & \multirow{3}{*}{$p$-value } & \multirow{3}{*}{$\begin{array}{c}\text { OR } \\
(95 \% \mathrm{CI})\end{array}$} \\
\hline & & \multicolumn{2}{|c|}{ Kasus } & \multicolumn{2}{|c|}{ Kontrol } & & & \\
\hline & & $\mathbf{n}$ & $\%$ & $\mathbf{n}$ & $\%$ & & & \\
\hline Tingkat Pendidikan & Pendidikan Dasar & 57 & 73,1 & 44 & 56,4 & 101 & 0,044 & 2,1 \\
\hline \multirow[t]{2}{*}{ Ibu } & Pend. Menengah/Tinggi & 21 & 26,9 & 34 & 43,6 & 55 & & $1,1-4,1$ \\
\hline & Jumlah & 78 & 100 & 78 & 100 & 156 & & \\
\hline Pekerjaan & Bekerja & 24 & 30,8 & 12 & 15,4 & 36 & 0,037 & 2,4 \\
\hline \multirow[t]{2}{*}{ Ibu } & Tidak Bekerja & 54 & 69,2 & 66 & 84,6 & 120 & & $1,1-5,3$ \\
\hline & Jumlah & 78 & 100 & 78 & 100 & 156 & & \\
\hline Tingkat & Pengetahuan Kurang & 49 & 62,8 & 35 & 44,9 & 84 & 0,037 & 2,1 \\
\hline \multirow[t]{2}{*}{ Pengetahuan Ibu } & Pengetahuan Baik & 29 & 37,2 & 43 & 55,1 & 72 & & $1,1-3,9$ \\
\hline & Jumlah & 78 & 100 & 78 & 100 & 156 & & \\
\hline Riwayat Penyakit & Ada Riwayat & 40 & 51,3 & 21 & 26,9 & 61 & 0,003 & 2,9 \\
\hline \multirow[t]{2}{*}{ Anak } & Tidak Ada Riwayat & 38 & 48,7 & 57 & 73,1 & 95 & & $1,5-5,6$ \\
\hline & Jumlah & 78 & 100 & 78 & 100 & 156 & & \\
\hline \multirow[t]{3}{*}{ Pola Asuh } & Kurang Baik & 57 & 73,1 & 44 & 56,4 & 101 & 0,044 & 2,1 \\
\hline & Baik & 21 & 29,6 & 34 & 43,6 & 55 & & $1,1-4,1$ \\
\hline & Jumlah & 78 & 100 & 78 & 100 & 156 & & \\
\hline
\end{tabular}

\section{ANALISIS MULTIVARIAT}

Analisis multivariat penelitian ini bertujuan diketahuinya variabel-variabel yang secara bersama-sama berhubungan dengan pertumbuhan Baduta, dan mengetahui variabel yang paling dominan berhubungan dengan pertumbuhan Baduta. Uji statistik yang digunakan adalah Regresi Logistik Ganda dengan menetapkan $\alpha=5 \%$. Langkah-langkah analisis multivariat pada penelitian ini adalah: analisis bivariat identifikasi kandidat model, analisis multivariat pemilihan model dan uji interaksi, dilanjutkan pembuatan model terbaik.

Tabel 3. Model Prediksi Faktor-faktor yang berhubungan dengan Pertumbuhan Baduta

95\% C.I. for $\operatorname{Exp}(B)$

B Sig. $\operatorname{Exp}(B)$ Lower Upper

\begin{tabular}{lccccc}
\hline $\begin{array}{l}\text { Tingkat } \\
\text { Pendidikan Ibu }\end{array}$ & 1,297 & 0,001 & 3,657 & 1,657 & 8,074 \\
$\begin{array}{l}\text { Status } \\
\text { Pekerjaan Ibu }\end{array}$ & 1,316 & 0,004 & 3,730 & 1,521 & 9,146 \\
Riwayat & 1,335 & 0,001 & 3,802 & 1,784 & 8,102 \\
Penyakit Anak & & & & & \\
Pola Asuh & 0,885 & 0,019 & 2,422 & 1,155 & 5,077 \\
Constant & - & 0,000 & 0,073 & & \\
& 2,616 & & & & \\
\hline
\end{tabular}

Berdasarkan pengumpulan data dan pengolahan data penelitian ini diperoleh model terbaik untuk memprediksi faktor-faktor yang berhubungan dengan pertumbuhan Baduta, sebagaimana tampak pada tabel 3 .

Berdasarkan tabel 3 dapat diketahui bahwa, Model/persamaan Logistik yang mempunyai kemaknaan statistik, adalah :

\section{$\mathrm{Z}=\alpha+\beta 1 \mathrm{X} 1+\beta 2 \mathrm{X} 2+\ldots . .+\beta \mathrm{iXi}$ \\ $=-2,616+1,335$ (Riwayat Peny. Anak) + 1,316 (Status Pekerjaan Ibu) + 1,297 (Tingkat Pendidikan Ibu) $+0,885$ (Pola Asuh)}

Berdasarkan nilai OR dari variabelvariabel dalam model tersebut dapat diketahui bahwa, Riwayat Penyakit Anak $(\mathrm{OR}=3,8)$ adalah variabel yang paling dominan berhubungan dengan pertumbuhan Baduta (umur 7-24 bulan) di wilayah kerja Puskesmas Penengahan 2015.

Probabilitas/peluang kejadian pertumbuhan Baduta (umur 7-24 bulan) tidak baik pada kondisi: ada riwayat penyakit anak (kode hasil ukur $=0$ ), ibu bekerja (kode hasil ukur=0), tingkat pendidikan ibu pendidikan dasar (kode hasil ukur=0), dan pola asuh tidak baik (kode hasil ukur $=0$ ), adalah: 


$$
\begin{aligned}
P(X) & =\frac{1}{1+e^{-z}} \\
& =\frac{1}{1+e^{-\left(\alpha+\Sigma \beta_{\mathrm{i}} X_{\mathrm{L}}\right)}} \\
= & \frac{1}{1+} e^{-[-2,616+1,335(0)+1,316(0)+1,297(0)+0,885(0)]} \\
& =\frac{1}{14,6798131} \\
& =0,068121(6,81 \%)
\end{aligned}
$$

Berdasarkan hasil perhitungan tersebut dapat disimpulkan bahwa, peluang kejadian pertumbuhan Baduta (umur 7 - 24 bulan) tidak baik pada kondisi : ada riwayat penyakit anak, ibu bekerja, tingkat pendidikan ibu pendidikan dasar, dan pola asuh tidak baik adalah sebesar $0,068121(6,81 \%)$.

\section{PEMBAHASAN}

Berdasarkan hasil penelitian dapat diketahui model prediksi faktor-faktor yang berhubungan dengan pertumbuhan Baduta (umur 7 - 24 bulan) di wilayah kerja Puskesmas Penengahan Kab. Lampung Selatan 2015. Model tersebut terdiri dari empat variabel tanpa variabel interaksi, yaitu: Riwayat Penyakit Anak $(\mathrm{p}=0,001, \quad \mathrm{OR}=3,8)$, Status Pekerjaan Ibu $(\mathrm{p}=0,004, \quad \mathrm{OR}=3,7)$, Tingkat Pendidikan Ibu $(\mathrm{p}=0,001, \mathrm{OR}=3,7)$, dan Pola Asuh $(p=0,019$, $\mathrm{OR}=2,4)$. Variabel yang paling dominan berhubungan dengan pertumbuhan Baduta adalah Riwayat Penyakit Anak (OR=3,8).

Beberapa ahli di bidang tumbuh kembang anak mengungkapkan konsep yang berbeda-beda tentang faktor-faktor yang mempengaruhi pertumbuhan seseorang, namun dapat disimpulkan beberapa hal yang sama tentang faktor-faktor tersebut. Hal yang sama tersebut adalah, bahwa pertumbuhan anak dipengaruhi oleh dua faktor utama yaitu faktor internal (genetik) dan faktor eksternal (lingkungan). Faktor internal antara lain faktor biologis, termasuk genetik, dan faktor eksternal (lingkungan) antara lain status gizi, riwayat penyakit anak, pekerjaan ibu, tingkat pendidikan ibu, pola asuh, dan lai-lain.

Hasil penelitian ini sejalan dengan teori yang diajukan oleh UNICEF dan Jonsson (1992) dan sejalan dengan Soetjiningsih (2014). UNICEF dan Jonsson (1992) mengajukan model pengaruh lingkungan terhadap tumbuh kembang anak. Model ini membedakan penyebab langsung, penyebab tidak langsung, dan penyebab dasar yang mempengaruhi tumbuh kembang anak. Penyebab langsung terdiri dari kecukupan makanan dan keadaan kesehatan. Penyebab tidak langsung terdiri dari ketahanan makanan keluarga, asuhan bagi ibu dan anak/pola asuh, serta pemanfaatan pelayanan kesehatan dan sanitasi lingkungan. Ketiga faktor tidak langsung tersebut saling berkaitan dan bersumber pada penyebab dasar yaitu potensi sumber daya yang mempengaruhi penyebab dasar lainnya yaitu struktur ekonomi, struktur politik dan ideologi.

Kecukupan makanan dan pola asuh anak dipengaruhi ketahanan pangan keluarga yang terkait dengan pendapatan keluarga, pekerjaan ibu, pendidikan ibu, serta pengetahuan ibu tentang gizi dan kesehatan. Pola asuh anak juga berkaitan dengan keadaan ibu/pengasuh dalam hal kesehatan, status gizi, pendidikan umum, pengetahuan tentang pengasuhan anak yang baik, peran dalam keluarga atau masyarakat, dan sebagainya. Keadaan kesehatan yang berpengaruh terhadap tumbuh kembang anak diantaranya adalah penyakit yang diderita anak yang dapat dipengaruhi oleh pemanfaatan pelayanan kesehatan dan sanitasi lingkungan (Soetjiningsih, 2014).

Hasil penelitian ini juga sejalan dengan hasil penelitian Kartikawati (2011). Pada hasil penelitian Kartikawati disebutkan bahwa, faktor yang paling dominan berpengaruh terhadap kejadian stunted dan merupakan faktor risiko adalah riwayat penyakit infeksi $(\mathrm{OR}=6,016)$. Hal tersebut dimungkinkan karena adanya kemiripan dalam karakteristik responden dan cakupan wilayah penelitian. Pada penelitian ini, dan penelitian Kartikawati, cakupan wilayah penelitian adalah kecamatan dengan karakteristik responden yang hampir sama yaitu responden yang tinggal di pedesaan.

Kaitan penyakit infeksi dengan pertumbuhan anak merupakan hubungan timbal balik yang saling mempengaruhi. Penyakit infeksi dapat memperburuk keadaan gizi, dan keadaan gizi yang buruk dapat mempermudah terkena infeksi. Penyakit infeksi juga dapat mempengaruhi nafsu makan anak, sehingga dapat mempengaruhi pemenuhan kecukupan gizi anak dan akhirnya akan menghambat pertumbuhan anak. Kurang makan meningkatkan risiko kurang gizi, dan risiko meningkat saat anak terserang penyakit dan semakin mengurangi asupan protein, mineral, dan zat gizi lain yang dibutuhkan anak agar tetap sehat. Anak sangat rentan terhadap gizi kurang ketika sebuah rumah tangga tidak punya cukup makanan, hidup dalam lingkungan yang memungkinkan diare serta penyakit lainnya. Hal tersebut yang 
memungkinkan bahwa riwayat penyakit anak menjadi faktor yang paling dominan terhadap pertumbuhan anak.

Hal yang memungkinkan riwayat penyakit anak menjadi faktor yang paling dominan terhadap pertumbuhan anak, selain hal tersebut diatas adalah bahwa anak yang mendapatkan makanan cukup baik tetapi sering diserang diare atau demam, akhirnya dapat menderita gizi kurang. Sebaliknya anak yang tidak memperoleh makanan cukup baik daya tahan tubuhnya dapat melemah. Dalam keadaan demikian anak mudah diserang infeksi, kurang nafsu makan, akhirnya kekurangan gizi dan menghambat pertumbuhannya. Pada kenyataan keduanya (makanan dan penyakit) secara bersama-sama merupakan penyebab langsung kekurangan gizi anak yang berdampak pada terhambatnya pertumbuhan anak.

Deteksi dini adanya penyakit yang diderita Baduta perlu dilakukan untuk mendapatkan penanganan yang adekuat sedini mungkin. Penanganan yang adekuat sedini mungkin diharapkan menyembuhkan penyakit sehingga tidak berpotensi menghambat pertumbuhan Baduta. Upaya deteksi dini adanya penyakit yang diderita Baduta dapat dilakukan oleh ibu dengan cara memantau adanya gejala penyakit dan setiap kelainan yang mungkin diderita anak, kemudian segera mengkonsultasikannya dengan petugas kesehatan. Pengetahuan tentang gejala dini penyakit berbahaya pada anak dapat diperoleh dari petugas kesehatan terdekat, dengan cara melakukan konseling dengan petugas kesehatan dan mengikuti setiap penyuluhan kesehatan yang dilakukan oleh petugas kesehatan.

Upaya untuk memberikan kekebalan terhadap penyakit berbahaya bagi anak juga perlu dilakukan, selain deteksi dini adanya penyakit yang diderita anak. Upaya tersebut antara lain: pemberian imunisasi lengkap sesuai umur anak, yang dapat diperoleh di Posyandu atau Puskesmas. Penting bagi ibu untuk selalu membawa anaknya ke Posyandu sampai umur lima tahun, agar dapat memantau pertumbuhan anaknya, mengetahui adanya kelainan atau penyakit sedini mungkin, dan mendapatkan imunisasi untuk memberikan kekebalan terhadap penyakit berbahaya yang dapat dicegah dengan imunisasi.

Secara substansi telah disebutkan bahwa, status pekerjaan ibu merupakan salah satu faktor yang berhubungan dengan tumbuh kembang anak. Hal tersebut dapat dibuktikan pada penelitian ini yang menujukkan bahwa status pekerjaan ibu merupakan salah satu faktor yang secara bersama-sama berhubungan dengan tumbuh kembang anak.

Ibu rumah tangga memiliki peran majemuk dalam keluarga dengan tanggung jawab terhadap suami, anak, dan anggota keluarga lainnya. Pada ibu yang bekerja, peran dan tanggung jawab tersebut bertambah dengan peran dan tanggung jawab mencari nafkah. Seringkali ibu yang bekerja, menyerahkan peran pengasuhan anaknya kepada orang lain. Hal tersebut dapat berpengaruh terhadap pertumbuhan anak, terutama karena adanya perbedaan rasa tanggung jawab antara ibu dan pengasuh lain. Ibu akan lebih bertanggung jawab terhadap baik atau tidaknya pertumbuhan anaknya, sedangkan pengasuh lain mungkin merasa tanggung jawabnya hanya sebatas menggantikan peran ibu sebagai pengasuh anak.

Ibu yang memiliki peran ganda seringkali dihadapkan pada konflik antara kepentingan pekerjaan dan keberadaannya dalam keluarga. Tuntutan pekerjaan yang menyita waktu seringkali menghambat kebersamaan dalam keluarga, merawat, dan mengasuh anak. Hal ini merupakan suatu tantangan bagi anggota keluarga untuk menyikapinya dengan bijaksana karena keseimbangan antara pekerjaan dan waktu untuk keluarga adalah hal yang utama dan harus dipenuhi.

Beberapa hal yang dapat dilakukan ibu yang bekerja, agar pertumbuhan anaknya dapat berjalan optimal, antara lain memberikan tanggung jawab sebagai pengganti peran pengasuhan ibu kepada orang yang dekat dengan anak secara psikis (misalnya kepada nenek atau kakeknya), meluangkan waktu untuk memantau aktivitas anak selama ibu bekerja, memanfaatkan waktu pada saat tidak bekerja atau sebelum dan sesudah bekerja untuk selalu dekat dengan anak, tidak membawa pekerjaan kantor untuk dikerjakan di rumah (bagi ibu yang bekerja di kantor), dan lain-lain.

Berdasarkan Model Logistik yang diperoleh dari keseluruhan langkah analisis data penelitian ini, dapat diketahui peluang kejadian pertumbuhan Baduta tidak baik pada kondisi semua variabel yang ada pada model dalam katagori tidak baik/berisiko adalah sebesar $0,068121(6,81 \%)$. Model Logistik tersebut terdiri dari variabel lingkungan yang berpengaruh terhadap tumbuh kembang anak. Oleh sebab itu, diperlukan upaya untuk meningkatkan kondisi lingkungan anak (Baduta) agar dapat mendukung tumbuh kembang anak yang optimal. Upayaupaya untuk mendukung tumbuh kembang anak yang optimal tersebut, sebagaimana telah diuraikan pada pembahasan tersebut di atas. 


\section{SIMPULAN}

1. Terdapat lebih dari separuh $(64,7 \%)$ ibu yang mempunyai Baduta (umur 7-24 bulan) dengan katagori tingkat pendidikan dasar, kurang dari seperempat $(23,1 \%)$ ibu yang mempunyai Baduta dengan katagori bekerja, lebih dari separuh $(53,8 \%)$ ibu yang mempunyai Baduta dengan katagori tingkat pengetahuan kurang, lebih dari seperempat $(39,1 \%)$ Baduta dengan katagori ada riwayat penyakit, lebih dari separuh $(64,7 \%)$ Baduta dengan katagori pola asuh kurang baik.

2. Ada hubungan yang bermakna antara tingkat pendidikan ibu $(p=0,001, \mathrm{OR}=3,7)$, antara antara status pekerjaan ibu $(p=0,004$, $\mathrm{OR}=3,7)$, antara riwayat penyakit anak $(p=0,001, \quad \mathrm{OR}=3,8), \quad$ antara pola asuh $(p=0,019$, OR=2,4), dengan pertumbuhan Baduta (umur 7-24 bulan). Tidak ada hubungan antara pengetahuan ibu dengan pertumbuhan Baduta $(\mathrm{p}=0,173)$.

3. Variabel yang secara bersama-sama berhubungan dengan pertumbuhan Baduta (umur 7-24 bulan), yaitu Riwayat Penyakit Anak $(p=0,001, \mathrm{OR}=3,8)$, Status Pekerjaan
Ibu $(p=0,004, \mathrm{OR}=3,7)$, Tingkat Pendidikan Ibu $(p=0,001, \quad \mathrm{OR}=3,7)$, dan Pola Asuh $(p=0,019, \quad \mathrm{OR}=2,4)$. Variabel yang paling dominan adalah Riwayat Penyakit Anak $(\mathrm{OR}=3,8)$.

\section{SARAN}

Beberapa saran untuk Puskesmas Penengahan Kab. Lampung Selatan dan Masyarakat, sebagai berikut:

1. Melakukan upaya deteksi dini adanya penyakit yang diderita anak untuk mendapatkan penanganan yang adekuat sedini mungkin.

2. Pemberian imunisasi lengkap sesuai umur anak dan selalu mengikuti kegiatan penimbangan di Posyandu sampai anak umur lima tahun.

3. Berperan aktif dalam kegiatan promosi kesehatan dan konseling tentang tumbuh kembang anak.

4. Melakukan evaluasi dan umpan balik terhadap setiap kegiatan penimbangan dan imunisasi di Posyandu.

\section{DAFTAR PUSTAKA}

Badan Litbang Kemenkes RI. 2013. Penyajian Pokok-pokok Hasil Riskesdas 2013. www.litbang.depkes.go.id

Dinkes. Prov. Lampung. 2015. Profil Kesehatan Provinsi Lampung Tahun 2014. Bandar Lampung.

Fajaria, Kartikawati Puji Rahayu. 2011. Faktor yang Mempengaruhi Kejadian Stunted Growth pada Anak Balita di Wilayah Kerja Puskesmas Arjasa Kabupaten Jember. Skripsi. FKM Universitas Jember.

Fauzi. 2011. Laporan Nasional Riskesdas 2011 2015. http://fauziarasj.blogspot.co.id/2011/06/laporannasional-riskesdas-2011-2015.html tanggal akses 26-03-2016.

Kemenkes RI. 2010. Pusat Promosi Kesehatan. Penuntun Hidup Sehat. Edisi Keempat. Jakarta.

Puskesmas Penengahan. 2015. Profil Puskesmas Penengahan Kab. Lampung Selatan. Penengahan.

Soetjiningsih. 2014. (Editor: IG.N. Gde Ranuh). Tumbuh Kembang Anak, Penerbit Buku Kedokteran. Jakarta: EGC.

Supariasa, I Dewa Nyoman, et al. 2002. Penilaian Status Gizi. Penerbit Buku Kedokteran. Jakarta: EGC.

Supartini, Yupi. 2012. Konsep Dasar Keperawatan Anak. Penerbit Buku Kedokteran. Jakarta: EGC. 